\title{
Describing eighteenth-century British satire
}

Book or Report Section

Accepted Version

Bullard, P. (2019) Describing eighteenth-century British satire. In: Bullard, P. (ed.) Oxford Handbook of Eighteenth-Century Satire. Oxford University Press, Oxford, UK. ISBN 9780198727835 Available at https://centaur.reading.ac.uk/82590/

It is advisable to refer to the publisher's version if you intend to cite from the work. See Guidance on citing.

Publisher: Oxford University Press

All outputs in CentAUR are protected by Intellectual Property Rights law, including copyright law. Copyright and IPR is retained by the creators or other copyright holders. Terms and conditions for use of this material are defined in the End User Agreement.

\section{www.reading.ac.uk/centaur}

\section{CentAUR}

Central Archive at the University of Reading

Reading's research outputs online 


\section{Describing Eighteenth-Century British Satire}

\section{Paddy Bullard}

The eighteenth century was an age of description. With their encyclopedias and howto books, their global voyages of discovery, their political economies and sciences of humanity, eighteenth-century writers set out to specify the world around them as comprehensively as they could. ${ }^{1}$ It was also an age of satire. These two generalizations do not sit easily with one another. Satire distorts, rather than describing things accurately: it shrinks human grandeur, it blows up blemishes; it sees hooves under the petticoat, and horns beneath the periwig. ${ }^{2}$ Moreover, satire is itself a phenomenon that resists definition and description. We think of it as a literary genre, but a glance through this handbook suggests that it works more like cultural virus, a

\footnotetext{
${ }^{1}$ See John B. Bender and Michael Marrinan, ed., Regimes of Description: In the Archive of the Eighteenth Century (Stanford: Stanford University Press, 2005); Cynthia Wall, The Prose of Things: Transformations of Description in the Eighteenth Century (Chicago: Chicago University Press, 2006); Joanna Stalnaker, The Unfinished Enlightenment: Description in the Age of the Encyclopedia (Ithaca: Cornell University Press, 2010).

${ }^{2}$ John Brown, in An Essay on Satire (1744), 12-13, combined these effects: satire 'Displays the cloven hoof, or lengthen'd ear; / Bids vice and folly take unborrow'd shapes...'; for contrary claims for the realism of satire cf. P.K. Elkin, The Augustan Defense of Satire (Oxford: Clarendon Press, 1973), 14, $82-3$.
} 
'mental position' that infects different sorts of art and literature, different kinds of speech and action, in many different ways. ${ }^{3}$

This prologue looks at some ways of describing satire, and of placing it in the British eighteenth century. It gathers a handful of extracts and anecdotes from the period, crossing-points at which different discussions of satire intersect with larger ideas about culture and society. Each extract has themes and contexts that need unpacking, and references to trace. Each represents a small shift in the way that satire was practiced or perceived.

The evidence collected here is anecdotal and fragmentary, so I have given it structure by arranging it in three sections. The first looks at some satirical commonalities. It considers the location of satire amongst scenes of associational life; it looks at the body of commonplace critical opinion that grew up around its practice; and it traces a connection with emerging constructions of British nationhood. The second turns to literary satire's material forms, looking across the bibliographical record to find patterns in the way it was consumed by readers of printed books. The third moves on from these generalized contexts to consider some of satire's personal, particular implications. The question of whether satire should always be general, whether it could avoid referring to individuals, preoccupied eighteenth-century commentators. Across the century there was an increasing critical focus on the ethical integrity of satirical writers, and much anxious discussion of what it meant to have a satirical 'humour'. By looking in turn across these three intersecting perspectives - communal,

\footnotetext{
${ }^{3}$ Charles A. Knight, The Literature of Satire (Cambridge University Press, 2004), 4; see also Dustin Griffin, Satire: A Critical Reintroduction (Lexington: University Press of Kentucky, 1994), especially $95-114$.
} 
material, personal - we can form a general impression of what eighteenth-century satire was, and how it developed.

\section{Satirical commonalities}

Despite the unreliability of its descriptions, there were plenty of enlightened, scientific people who embraced the century's spirit of ridicule. Richard Lovell Edgeworth, the educational reformer and gentleman-engineer, belonged to a London club that met weekly at Slaughter's Coffee House in the early 1780s. Its members were writers, explorers and natural scientists, including the surgeon John Hunter, Joseph Banks (recently elected President of the Royal Society), Nevil Maskelyne (the Astronomer Royal), and Captain Cook himself. ${ }^{4}$ Getting into the club was hard. New members endured a sort of trial by satire, as Edgeworth recalled in his memoirs:

...we practised every means in our power, except personal insult, to try the temper and understanding of each candidate for admission. Every prejudice, which his profession or situation in life might have led him to cherish, was attacked, exposed to argument and ridicule. The argument was always ingenious, and the ridicule sometimes coarse. This ordeal prevented for some time the aspiration of too numerous candidates; but private attachments at length softened the

\footnotetext{
${ }^{4}$ For another account of the club and its connection with the Lunar Society of Birmingham, see Eric Robinson, 'R. E. Raspe, Franklin's 'Club of Thirteen', and the Lunar Society', Annals of Science 11 (1955), 142-4.
} 
rigour of probation, the society became too numerous, and too noble, and was insensibly dissolved. ${ }^{5}$

The self-consciousness with which the club at Slaughter's Coffee House created a ritual out of ridicule is itself distinctive. It is hard to think of another age or place in which a culture of satire could be so generally, and to some extent tacitly, understood. Edgeworth touches on several themes that crop up repeatedly in the pages of this handbook. First, he recalls how the club's tests focused on people's 'profession or situation in life'. Eighteenth-century satire often lingered over social descriptions and occupational identities, worrying about the individual in the group. 'I have ever hated all nations, professions, and communities', wrote the satirist Jonathan Swift in a famous letter, '... but principally I hate and detest that animal called man, although I heartily love John, Peter, Thomas, and so forth'. ${ }^{6}$ Satire's interest in groups and individuals was complicated by the tendency of satirists to set themselves amid scenes of associational life, like the one painted here. ${ }^{7}$ Second, Edgeworth balances 'ingenious' argument against 'coarse' ridicule. Again, that simple combination evokes a century of debates about polite wit and pedantry, about philosophers using ridicule as a test for truth, about whether it is appropriate for satirists to smile or to snarl. ${ }^{8}$ Above all Edgeworth is describing a practice of satire here. Hugh Kenner once argued that satire is parasitic on literary technologies and genres, and on them alone: 'It requires that the language by which we recount events be externalized for inspection,

\footnotetext{
${ }^{5}$ Memoirs of Richard Lovel Edgeworth, Begun by Himself and Concluded by his Daughter, Maria Edgeworth, 2 vols. (1820), i. 189.

${ }^{6}$ Swift to Pope, 29 September 1725, Swift, Corr. (Woolley), ii. 606-7.

${ }^{7}$ See Hawley2, Southcombe4, Rounce7

${ }^{8}$ See Loveman, Klein
} 
the way only writing externalizes'. ${ }^{9}$ The mere talker can mock, in other words, but cannot satirize. But the club at Slaughter's coffeehouse shows how satire could manifest itself through social codes as well as literary ones. Third, Edgeworth describes a specific instrument of exclusion - the trial that puts off crowds and unwanted noblemen - that is embedded within a larger public system of exclusions. As Maria Edgeworth will have noticed while she transcribed her father's reminiscences, women do not qualify even as candidates for this scientific club. But they had other ways to participate in the age's rituals of ridicule, as her satirical novels had so often proved. ${ }^{10}$ Ultimately, the club dissolves when the rigours of its initiation ceremony are softened. Here once again the club's story corresponds with a familiar narrative about satire in the eighteenth century, one that needs much qualification: that it slowly fell out of fashion in an age of science and sensibility. ${ }^{11}$

The century's spirit of ridicule took polite and sentimental forms, as well as forms that externalized and excluded. While the variety of these forms created problems of definition - which in turn prompted many careful essays on the differences between satire, raillery, libel and burlesque - eighteenth century people generally knew what to think about them. ${ }^{12}$ Horace, Persius and Juvenal remained staples of schoolroom and

\footnotetext{
${ }^{9}$ Hugh Kenner, 'Wyndham Lewis: The Satirist as Barbarian', in English Satire and the Satiric Tradition, ed. Claude Rawson (London: Blackwell, 1984), 264-75, at 265.

${ }^{10}$ See David Francis Taylor, 'Edgeworth's Belinda and the Gendering of Caricature', 26 (2014), 593624.

${ }^{11}$ See Festa38

${ }^{12}$ See Latimer24, Taylor38, Hone18, Tadié19. For an basic eighteenth-century taxonomy of satire and its varieties see Corbyn Morris, Essay on Wit and Humour (1744), 50-1; for a thorough modern taxonomy see Ashley Marshall, The Practice of Satire in England, 1658-1770 (Baltimore: Johns Hopkins University Press, 2013).
} 
academy, and a tradition of humanistic scholarship and debate about the classical canon of satire was readily accessible, digested, for example, in John Dryden's 'Discourse on Satire' (1693). ${ }^{13}$ In the vernacular realm, opinions had settled in part because satire's moral ambivalence made it such a good topic for the conventionalized discourse of the periodicals and, at a personal level, for commonplace books. ${ }^{14}$ Samuel Richardson seems to have turned to his as he drafted Clarissa Harlowe's sixty-ninth letter, where she taxes her friend Anna Howe with a satirical (albeit perfectly tactful) mind:

What patient shall be afraid of a probe in so delicate a hand? - I say I am almost afraid to pray to you give way to it, for fear you should, for that very reason, restrain it. For the edge may be taken off, if it does not make the subject of its raillery wince a little. Permitted and desired satire may be apt, in a generous satirist, mending as it rallies, to turn too soon into panegyric. Yours is intended to instruct; and though it bites, it pleases at the same time: no fear of a wound's rankling or festering by so delicate a point as you carry; not envenomed by personality, not intending to expose, or ridicule, or exasperate. The most admired of our moderns know nothing of this art. Why? Because it must be founded in good nature, and directed by a right heart. The man, not the fault, is generally the subject of their satire: and were it to be just, how should it be useful? How should it

\footnotetext{
${ }^{13}$ See Haugen11, Augustine12, Fowler35; see William Kupersmith, English Versions of Roman Satire in the Earlier Eighteenth Century (Newark: University of Delaware Press, 2007), and Roman Satirists in Seventeenth-Century England (Lincoln: University of Nebraska Press, 1985).

${ }^{14}$ See Marshall15, Baines22
} 
answer any good purpose? When every gash (for their weapon is the broadsword, not a lancet) lets in the air of public ridicule, and exasperates where it should heal. ${ }^{15}$

Several of these thoughts would be filleted out as commonplaces in the 'Collection of Moral and Instructive Sentences' that Richardson prepared for readers of Clarissa in 1751. ${ }^{16}$ Others had been worn smooth by tradition. For example, Clarissa's main theme is classical. The Roman poet Persius had railed admiringly at his predecessor Horace for performing a sort of secret moral surgery with his satires: 'While his friend is laughing, the rascal Horace touches every fault in him and, once he's got in, he frolics around his heart'. ${ }^{17}$ The delicately 'probing' hand of Anna Howe is imagined following the Horatian example, albeit with less laughter going around. Clarissa's worry about the wound from satire 'rankling or festering' owes something to Joseph Addison's warning that 'lampoons and satires, that are written with wit and spirit, are like poisoned darts, which not only inflict a wound, but make it incurable', issued in Spectator no. 23 (27 March 1711). ${ }^{18}$ Periodicals are also the source for her hopeful insistence that satire should be 'founded in good nature'. Richard Steele complained

\footnotetext{
${ }^{15}$ Samuel Richardson, Clarissa: or, The History of a Young Lady, ed. Angus Ross, 2 vols. (Aylesbury: BPCC Hazell Books, 1991), i. 280.

${ }^{16}$ A Collection of the Moral and Instructive Sentiments... Contained in the Histories of Pamela, Clarissa... (1755), in Samuel Richardson's Published Commentary on Clarissa, 1747-65, ed. O.M. Brack et al., 3 vols. (London: Pickering and Chatto), iii. 200-1.

${ }^{17}$ Persius, Satires, in Juvenal And Persius, ed. Susanna Morton Braund (Cambridge: Harvard University Press, 2004), 58 [1.116-7]; the line had been a favourite of British commonplacers since Sir Philip Sidney used it in An Apology for Poetry (1595): see English Renaissance Literary Criticism, ed. Brian Vickers (Oxford: Oxford University Press, 1994), 361-2.
}

${ }^{18}$ Spectator, i. 97 
in Tatler no. 242 about 'Smart Satirical Fellows' about town who are 'by no means qualified for the Characters they pretend to... because they want Good-nature'. ${ }^{19}$ Addison and Steele were the century's great reformers of raillery, and Clarissa is entirely of their party, but she draws on writers who were less scrupulous about the collateral effects of satire as well. Her image of the 'edge' of satire working like a lancet (or broadsword) belongs to a well-known passage in John Dryden's 'Discourse Concerning Satire' that contrasts 'the slovenly butchering of a man, and the fineness of a stroke that separates the head from the body and leaves it standing in its place' ${ }^{20}$ It was Jonathan Swift who appropriated the idea of satire as a surgical instrument most often to his own writing. ${ }^{21}$ This body of commonplace imagery and opinion concerning satire could serve as a resource and as a provocation for eighteenthcentury writers, even where definitions of satire did not keep up with contemporary practice.

If satirists often positioned themselves at tea-tables, clubs and coffee-houses, and if the companies they found there shared a body of opinion about what ridicule was and what it did, is it possible to place these commonalities in any larger setting? It seemed natural for eighteenth-century Britons to think about satire as a national habit, bound up with their weather, with their constitution, and with the humour of the people. ${ }^{22}$ In his last sermon Archbishop Tillotson regretted that he had lived to see an age in which satire and evil speech had become a national entertainment: "Tis the Sawce of

\footnotetext{
${ }^{19}$ Tatler, iii. 241.

20 'Discourse Concerning Satire', Dryden, Poems (Longman), iii. 423.

${ }^{21}$ see Robinson37; also see Paddy Bullard, 'Swift's Razor’, Modern Philology 113 (2016), 353-372.

${ }^{22}$ See Thomas R. Preston, Not in Timon's Manner: Feeling, Misanthropy, and Satire in EighteenthCentury England (University of Alabama Press, 1975), 14-19; Knight, Literature of Satire, 50-80.
} 
Conversation, and all Discourse is counted but flat and dull which hath not something of piquancy and sharpness in it against some body'. ${ }^{23}$ His contemporary the diplomat and essayist Sir William Temple worried about the nation's 'Vein of Ridiculing' in 1690: "Tis the Itch of our Age and Clymat, and has over-run both the Court and the Stage, $[\ldots]$ and I have known in my Life, more than one or two Ministers of State, that would rather have said a Witty thing, than done a Wise one'. ${ }^{24}$ Perhaps as he wrote this Temple was thinking about the court of Charles II rather than that of William III - the echo of Rochester's satire on the former king, who 'never said a foolish thing, / Nor ever did a wise one', is a give-away. ${ }^{25}$ In any case, the British climate, in its very instability, is a constant factor. Lawrence Sterne attributed to climate the ascendancy of English character satire over that of France: 'this strange irregularity in our climate, producing so strange an irregularity in our characters,-doth thereby, in some sort, make us amends, by giving us somewhat to make us merry with when the weather will not suffer us to go out of doors'. ${ }^{26}$ But Sterne's daughter Lydia, returning from residence on the continent after her father's death in January 1769, made a darker comparison between the two nations. Her correspondent

\footnotetext{
${ }^{23}$ John Tillotson, The Last Sermon of his Grace John late Lord Archbishop of (1695), 13; Tillotson borrows from his fellow latitudinarian divine Isaac Barrow, as he often did: see Barrow, Several Sermons Against Evil Speaking (1678), 56: 'this Age, wherein plain Reason is deemed a dull and heavy thing... cannot relish any food without some piquant sawce...'

${ }^{24}$ Sir William Temple, 'Upon Ancient and Modern Learning', in Miscellanea. The Second Part (1690), 74.

${ }^{25}$ Rochester, Works, 292-4.

${ }^{26}$ Laurence Sterne, The Life and Opinions of Tristram Shandy, ed. Melvyn New and Joan New, 3 vols. (Gainesville: Florida University Press, 1978), i. 71.
} 
Elizabeth Montagu, doyenne of the Bluestockings, asked Lydia whether she had inherited her father's wit, which the daughter denied rather hotly:

- I look upon satire with detestation and I must own when we returned from france we were much hurt with the satirical things we heard in every company we went into, having lived six Years amongst people who know not what it is to be satirical. ${ }^{27}$

It may be that satire was associated particularly with the British eighteenth century because the national character seemed to blend Shandean humorousness with the more melancholy, aggressive satirical turn experienced by Lydia Sterne. 'The English have greatly changed within this century', wrote the traveller Gebhard Wendeborn in 1791; 'they have grown more gay... it, therefore, cannot be said, as I have frequently heard abroad, that their blood, by nature, is blacker and thicker than that of other nations' ${ }^{28}$ But the black blood was perhaps more persistent than he thought.

\section{Satirical materials}

Thinking about the commonalities of eighteenth-century British society in which satire came to prominence helps us begin to place it in this period. These commonalities included, as we have seen, those of associational life, of literary culture, and of national identity. But looking at satire's material forms can also give a general sense of its significance to the age. Satire appeared in an extraordinary variety

\footnotetext{
${ }^{27}$ Lydia Sterne to Elizabeth Montagu, January 1769, in Laurence Sterne, The Letters, Part 2: 1765 1768, ed. Melvyn New and Peter de Voogd (Gainesville: University of Florida Press, 2009), 733.

${ }^{28}$ Gebhard Wendeborn, A View of England towards the Close of the Eighteenth Century (1791), 404.
} 
of shapes and manifestations, sprawling across the media. Of course its impact as a mode for graphic art was especially important. ${ }^{29}$ Several essays in this volume look at satire's trajectories still further from the literary, the way it spilled out into oral expressions, into personal enactments and performances, into things themselves. ${ }^{30}$ Looking at the range of media in which satire appeared also makes us reconsider the materiality of its literary forms. Satire's significance to late seventeenth-century manuscript culture is well known, but (at the risk of stating the obvious) it was in the form of printed books, pamphlets and broadsides that it found its way into all libraries, and into every reader's hand. ${ }^{31}$ One great advantage of printed literary media to this survey is that eighteenth-century books are minutely catalogued on the ESTC electronic database, which means that books of satire can be counted and categorized by automatic mechanisms. This in turn allows us to identify some general historical trends in the production and consumption of printed satire.

One way of measuring satire's impact on the eighteenth century book trade is to look at the number of imprints booksellers were able to sell of early editions, and the frequency with which texts were reprinted. ${ }^{32}$ These are yardsticks that show how a handful of satires established themselves among the most popular and long-lived publications of the century. The best-known satires sold strongly as single-title publications, and then continued to be read as anthology pieces. John Dryden's Absalom and Achitophel (1681) went through seven editions within a year of

\footnotetext{
${ }^{29}$ Molesworth, Taylor.

${ }^{30}$ Loveman, McTague, Silver.

${ }^{31}$ Harold Love, English Clandestine Satire, 1660-1702 (Oxford: Oxford University Press, 2004)

${ }^{32}$ For the reprint trade see T.F. Bonnell, The Most Disreputable Trade: Publishing the Classics of English Poetry, 1765-1810 (Oxford, 2008)
} 
publication, two of them styled 'second', and had reached a 'tenth' by 1701 . But it was its prominent position as the second poem in the continuously re-printed DrydenTonson Miscellany Poems (1685) that consolidated its place in the canon. Jonathan Swift's difficult satire on modern learning and religion, A Tale of a Tub, is an unlikely candidate for popularity. ${ }^{33}$ But it was much reprinted after its publication in 1704, often in tiny, cheap formats, with four distinct 'small duodecimo' editions appearing in 1711 alone. The Tub's longevity as a stand-alone publication - Charles Barthurst issued a 'fifteenth' edition in 1766 - was due in part to Swift's reluctance to acknowledge authorship by including it in his Miscellany collections during his lifetime (although it did appear in editions of his works after 1743). Alexander Pope's The Rape of the Lock (1714) was a phenomenon of the trade: a year after publication Pope boasted of 'the uncommon Sale of this Book (for above 6000 of 'em have been already vended)'. ${ }^{34}$ These are 'surprisingly large figures' for the print run of a poem, writes David Foxon: 'the nearest I know is the 2000 and 250 fine copies of [John] Gay's Trivia printed in January $1716,{ }^{35}$ What makes them more surprising is that the Rape had appeared already in the Pope-edited Miscellaneous Poems and Translations of 1712. Notwithstanding its frequent inclusion in anthologies and collected editions, the Rape reached a 'sixth' stand-alone edition in 1726 . The canonical status that these three works retain to this day is underlined by their lucrative history as bookseller's copy.

\footnotetext{
${ }^{33}$ See Walsh.

${ }^{34}$ Alexander Pope, A Key to the Lock [...] by Esdras Barnivelt, apoth (1715), 'Epistle Dedicatory', iv.

${ }^{35}$ David Foxon, Pope and the Early Eighteenth-Century Book Trade, ed. James McLaverty (Oxford: Clarendon Press, 1991), 42.
} 
Stories of prodigious popularity can be told about the other very well-known satires written by Swift, Pope and their ‘Scriblerian' circle. John Arbuthnot's History of John Bull was a series of satires on European politics during the War of Spanish Succession. The first pamphlet in the sequence, The Law is a Bottomless-Pit, ran to nine impressions in 1712 , but their initial popularity was short-lived. Rescued from oblivion in 1727 by inclusion in the Pope-Swift Miscellanies, however, they appeared, unattributed to Arbuthnot, in collections of Swift's works into the nineteenth century. It is less easy to sum up the complicated publication histories and vast popularity of the three most famous 'Scriblerian' satires of the late 1720s, Swift's Gulliver's Travels (1726), John Gay's Beggar's Opera (1728) and Pope's original Dunciad (1728). Swift for one imagined them occupying successively the same high-ground of success: 'The Beggars Opera hath knockt down Gulliver', he told Gay in 1728, 'I hope to see Popes Dullness knock down the Beggars Opera, but not till it hath fully done its Jobb'. ${ }^{36}$ Tales of astonishingly rapid early sales circulated. Ten days after Gulliver appeared Gay and Pope assured Swift that it 'hath been the conversation of the whole town ever since: The whole impression sold in a week'. ${ }^{37}$ There was gratifying chaos when The Dunciad first appeared: 'a crowd of authors besieged [Anne Dodd's] shop', as Richard Savage recalled, '...to hinder the coming-out of The Dunciad: on the other side, the booksellers and hawkers made as great efforts to procure it. What could a few poor authors do against so great a majority as the

\footnotetext{
${ }^{36}$ Swift, Corr. (Woolley), iii. 171; cf. iii. 181: 'there is now a vacancy for fame; the Beggar's Opera hath done its task'.

${ }^{37}$ Swift, Corr. (Woolley), iii. 47.
} 
publick? There was no stopping a torrent with a finger, so out it came' ${ }^{38}$ For Swift, the fact of popular success gave a peculiar moral weight to his satires: drawn to comment on Swift's works in verse and prose, his imagined eulogist in Verses on the Death of Dr. Swift declines to adjudicate: 'Nor, can I tell what Criticks thought 'em; / But, this I know, all People bought 'em'. ${ }^{39}$ There is little in the bibliographical record to challenge all this excitement, self-congratulation and back-slapping.

One indication of the reach that eighteenth-century satires could have is that Daniel Defoe achieved the greatest success of his career, not with the Review or Robinson Crusoe, but with a verse satire, The True-Born Englishman (1701). Like John Bull it was a work of its time, written in response to an anti-Williamite lampoon by John Tutchin called The Foreigners (1700), and yet it continued to appear in edition after edition through the century. A 'twenty-fifth' was issued in 1777, and the ESTC lists seven more up to 1795 . It was also one of the period's most pirated works, so even these numbers tell only part of the story. In 1705 Defoe claimed that, beside the nine one-shilling 'official' editions that had appeared by that date, The True-Born Englishman 'has been Twelve Times printed by other Hands... 80000 of the Small Ones have been sold in the Streets for $2 \mathrm{~d}$. or at a Penny' - an over-enthusiastic compositor perhaps adding an extra zero to that extraordinary figure. ${ }^{40}$ Other satires that enjoyed enduring popularity as stand-alone publications included Sir Samuel

\footnotetext{
${ }^{38}$ Richard Savage, A Collection of Pieces in Verse and Prose (1732), vi; Johnson attributed this to Pope, presumably on Savage's authority: Samuel Johnson, Lives of the Most Eminent English Poets, ed. Roger Lonsdale, 4 vols. (Oxford: Clarendon Press, 2006), iv. 32.

${ }^{39}$ Swift, Poems (Williams), ii. 565.

${ }^{40}$ See P.N. Furbank and W.R. Owens, A Critical Bibliography of Daniel Defoe (London: Pickering and Chatto, 1998), 3-6.
} 
Garth's The Dispensary (1699), which reached a 'ninth' edition in 1726 and an 'eleventh' in 1768. Lady Mary Wortley Montagu's Verses Address'd to the Imitator of the First Satire of the Second Book of Horace (1733), written collaboratively with John, Baron Hervey, reached a 'sixth' edition in 1735 . That tally includes neither the 1733 Dublin edition nor a rival first edition (titled To the Imitator of the Satire) apparently issued by Hervey himself. ${ }^{41}$ Its target, Pope's First Satire of the Second Book of Horace, Imitated, was perhaps a shade less popular, appearing in several different formats and six impressions (plus two Dublin printings and an Edinburgh false imprint) in 1733-4. Slightly later in the century, Christopher Anstey's jolly social satire The New Bath Guide was very widely read from 1766, prompting dozens of imitators to adopt its galloping anapestic style. The Dodsleys issued a 'fourteenth' edition in 1791, with four more editions before end of century. It is worth mentioning here that satire set up the Dodsley publishing business in the first place. In 1735 Robert Dodsley had combined the profits from his after-piece The Toy-Shop: A Dramatick Satire with a contribution of $£ 100$ from Alexander Pope, allowing him to establish his famous premises in Pall Mall. The Toy-Shop continued to sell well, sixteen editions appearing with the Dodsley imprint before the end of the century.

There is evidence that this handful of very well-known satires sold rapidly on their publication and remained popular over several years. But this is not to imply that the market remained level: both supply and demand for printed satire fluctuated significantly during the eighteenth century. The British Library's electronic edition of the ESTC allows us to make a rough sketch of the shifting market for satire between

\footnotetext{
${ }^{41}$ D.F. Foxon, English Verse 1701-1750: A Catalogue of Separately Printed Poems, 2 vols. (Cambridge University Press, 1975), i.838-9.
} 
1650 and $1800 .^{42}$ The following graph plots year-by-year figures generated by the widest possible searches of the ESTC for individual publications that feature words with the roots 'satir-' or 'saytr-' in their long titles, or that have had those words applied to them by modern cataloguers. Bibliometric analyses of databases are best done by sampling - by examining records for single years at ten-year intervals, for example - so that the analyst has a chance to screen their data in a series of reduced sets. ${ }^{43}$ But the number of satire-related publications fluctuated unpredictably from one year to the next: a selective method will not work here. The raw data still needs to be contextualized. The production and sale of printed books was affected across the period by volatility in financial markets (bookselling was a highly capitalized trade), by costs of raw materials (especially imported ones like paper), and by expanding or contracting capacity in the trade more generally, among other dynamic factors. ${ }^{44}$ In order to register these factors I have divided the annual figures for my word-search on 'satir-' by the total number of titles registered on the ESTC for each year. At the same time I have added records for a few well-known texts that did not come up on my initial word search. It never occurred to the ESTC's cataloguers to note, for example, that many people (if not everyone) describe The Rape of the Lock and Gulliver's Travels as satires. The resulting sets of figures constitute some very 'noisy' data, but

\footnotetext{
${ }^{42}$ http://estc.bl.uk, site accessed 8 September 2017; for the ESTC in period context see Paddy Bullard, 'Digital Humanities and Electronic Resources in the Long Eighteenth Century', Literature Compass (2013), 1-13, 10.1111/lic3.12085

${ }^{43}$ Sampling methods are discussed by Michael Suarez, 'Towards a Bibliometric Analysis of the Surviving Record, 1701-1800', in The Cambridge History of the Book in Britain, Volume V: 1695 1830 (Cambridge: Cambridge University Press, 2010), 37-65, at 41-3.

${ }^{44}$ See James Raven, Publishing Business in Eighteenth-Century England (Woodbridge: Boydell Press, 2014), 33-51.
} 
across a century and a half they allow us to recognize distinct correlations and patterns.

[insert graph here]

In terms of publication patterns for satire the graph indicates a contrast between the first and second halves of the period 1650-1800. Before c.1725 the proportion of published titles identified as satires was apt to fluctuate suddenly, with particular years $(1660,1682,1710)$ showing dramatic, short-lived increases. ${ }^{45}$ After c. 1725 one can see a stronger medium-term correlation amid annual variations, with the market share of 'satir-' titles declining steadily across the decades to the century's end. The relatively distinct trend that emerges in the second half of the period can be explained in part by the growing capacity of the book trade. ${ }^{46}$ The total number of titles published annually increases across the century, and larger samples absorb local fluctuations in the numbers. But it is only from the 1770s that annual increases in overall book production begin rising steeply, and the correlation is established during the preceding half-century of more steady growth.

If we look for peaks in satire production, the graph shows spikes at the points we would expect it to on the evidence of received literary history. The most dramatic

\footnotetext{
${ }^{45}$ General spikes in numbers of surviving titles for these years can be see in the graph for book production illustrated in James Raven, The Business of Books: Booksellers and the English Book Trade (New Haven: Yale University Press, 2007), 8, to which 'satir-' titles evidently made a significant contribution.

${ }^{46}$ For context see Raven, Business of Books, 131-4, and Suarez, 'Bibliometric Analysis', 43-5.
} 
spike occurs in 1681-2, years of extraordinary political ferment that saw the Exclusion Crisis and the publication of John Dryden's satire Absolom and Achitophel. We should not assume, of course, that the 277 titles returned by a search for 'satir-' over these years are all, like Dryden's quarto, recognizable as 'literary' productions. The ESTC lists 169 of those titles as single-sheet ballad-style publications, and a similar proportion (49 out of 117) of 'satir-' titles take broadside formats in 1660. By 1728 these proportions have fallen, with about a quarter of the 88 'satir-' titles returned being single-sheet productions, whereas half of them are now octavo books or pamphlets.

More generally, the graph indicates that consistently higher proportions of 'satir-' titles were published during periods of heightened political activity and excitement. There are distinct 'shoulders' to peaks seen in 1710-1714, the turbulent four last years of Queen Anne's reign and of the Tory 'paper wars'. There is another peak in c.17261730, when Bolingbroke was reviving those paper wars with The Craftsman, and when Gullivers Travels, The Beggars Opera and The Dunciad were enjoying the first flush of their success. Other shouldered peaks are identifiable with the period between Walpole's Excise Bill of 1733 and the Licensing Act of 1737, when his ministry was especially hard pressed; with the years around his fall from office in 1742; and later with the Earl of Bute's controversial ministry, c.1762. The graph does not reflect the turbulent political culture of the late 1760 s, the period of John Wilkes's Middlesex Election dispute and of The Letters of Junius, as one might expect it to, but there is another predictable set of shouldered peaks after 1774, corresponding with the American revolutionary wars. 
So the noisy data from these ESTC searches allows us to make a few tentative, though broad-ranging conclusions about the material production of satire in the long eighteenth century. First, the publication rates of satirical titles, be they popular, polemical or literary, correlate noticeably with periods of turbulence and excitement in high politics, and they recede again in periods of relative socio-political stability, such as the first decades of the reigns of William III (acc. 1689) and George I (acc. 1714). Second, the exceptionally popular single-title satires discussed above tend to appear during these years of political restlessness. Third, after about 1750 satire lost a capacity to make sudden increases in its share of the book trade: it no longer passed dramatically in and out of fashion as it had in 1681-2, 1710-14 or 1727-30. In the later century satire occupied a settled place in the cultural landscape, but never again made such a distinctive feature in the scene.

\section{Satirical personalities}

So far we have looked at anecdotes that reflect some commonalities of eighteenthcentury satire - in associational life, in a tradition of commonplace, in national identity - and we have made a general survey of the period's printed satire by searching for patterns in the bibliographical record. It often suits satirists, as well as historians of satire, to rise above the level of the particular like this: 'Come on then Satire!' urges Pope in the Epilogue to the Satires, 'gen'ral, unconfin'd / Spread thy broad wing, and sowze on all the Kind'. ${ }^{47}$ Sooner or later, however, the personal and the individual reassert themselves. Pope was as willing as any of his contemporaries to acknowledge the virtue of general satire, but he was impatient with its lack of

\footnotetext{
${ }^{47}$ Pope, Poems (Twickenham), iv. 314.
} 
force: 'People have ceas'd to be ashamed of [general satire] when so many are joined with them', he complained to Arbuthnot; 'and tis only by hunting One or two from the Herd that an Example can be made'. ${ }^{48}$ Satires may paint composite or group portraits, but they will be consumed ultimately by readers as individuals, and satirists found irony in this as well. 'I am not conscious of the least malevolence to any particular person thro' all the Characters', claimed Edward Young in the preface to his Love of Fame satires; 'tho' some persons may be so selfish, as to engross a general application to themselves' ${ }^{49}$ Henry Fielding insisted that Joseph Andrews is a novel that describes 'not Men, but Manners; not an Individual, but a Species': as such its satire is 'calculated for much more general and noble Purposes, than to expose one pitiful Wretch, to the small Circle of his Acquaintance; but to hold the Glass to thousands in their Closets, that they may contemplate their Deformity'. ${ }^{50}$ The important point here is that the deformed thousands have no corporate body. Satire is experienced by particular readers, shut up alone in their closets. The movements that satire made between the general and the personal, the public and the private, were understood to cut more deeply than mere fiction into the personal sphere. ${ }^{51}$ This had implications for the moral claims that satirists made, as well as for the experience of individual readers.

\footnotetext{
${ }^{48}$ Pope to Arbuthnot, published version, dated 26 July 1734, Alexander Pope, Selected Letters, ed. Howard Erskine-Hill (Oxford: Oxford University Press, 2000), 248; for a conspectus of eighteenthcentury statements on general vs. personal satire see Elkin, Augustan Defence, 118-45.

${ }^{49}$ Young, Love of Fame, A2r.

${ }^{50}$ Fielding, The History of the Adventures of Joseph Andrews, 2 vols. (1742), ii. 5-6.

${ }^{51}$ Michael McKeon, The Secret History of Domesticity: Public, Private and the Division of Knowledge (Baltimore: Johns Hopkins University Press, 2005), 83-5, 95-99.
} 
There is a striking example of the pressure that the debate about general satire could put on the moral characterization of an individual satirist in Samuel Johnson's Dictionary of the English Language (1755). Johnson chose three literary examples to illustrate his definition for the word 'SÁTRIST. n.f. [from satire]. One who writes satires'. Arranged as a group, it is clear that the reader is expected to spot a link between the quotations, which are laid out in this order:

Wycherly, in his writing, is the sharpest satirist of his time; but, in his nature, he has all the softness of the tenderest disposition: in his writings, he is severe, bold, undertaking; in his nature gentle, modest, inoffensive. Granville.

All vain pretenders have been constantly the topicks of the most candid satyrists, from the Codrus of Juvenal to the Damon of Boileau. Letter to the Publisher of the Dunciad.

Yet soft his nature, though severe his lay;

His anger moral, and his wisdom gay:

Blest satirist, who touch'd the mean so true,

As show'd vice had his hate and pity too. Pope. ${ }^{52}$

The first quotation comes from a 'Character' of William Wycherley written by his fellow dramatist George Granville, Lord Lansdown, to whom Pope dedicated Windsor

\footnotetext{
${ }^{52}$ Samuel Johnson, A Dictionary of the English Language, 2 vols. (1755), ii. 'Satirist'.
} 
Forest. ${ }^{53}$ The second and third are both by Alexander Pope: one is from The Dunciad's prefatory material, the other from an epitaph for Charles, Earl of Dorset, published in 1735. In the criticism of Pope's epitaphs that Johnson wrote in 1756 for The Universal Visitor, later republished in his life of Pope, the line 'Yet soft his nature, though severe his lay,' is described as 'a high compliment, but was not first bestowed on Dorset by Pope'. ${ }^{54}$ Johnson makes no specific attribution. In terms of general sense, an obvious precedent is the Earl of Rochester's famous lines in 'An Allusion to Horace', where Dorset is singled out as supreme contemporary satirist, 'The best good Man, with the worst-natur'd Muse' ${ }^{55}$ But the sequence of quotations that Johnson selected for the Dictionary indicates that Pope has borrowed from Granville - the 'Character' of Wycherley does indeed anticipate Pope's opposition of 'soft' and 'severe'. 56

The attribution is so obscure that Johnson preferred, perhaps, not to make an open claim. But the second of the Dictionary's three quotations shows there was also a more important point that he wanted to add. In the 'Letter to the Publisher of the ${ }^{53}$ George Granville, 'Character of Mr. Wycherley', in Charles Gildon, Memoirs of the Life of William Wycherley (1718), 23-6. Pope, whose earliest writings are praised by Granville in the 'Character', quotes that praise in the 1736 Works, vol. 1 (Pope, Poems (Twickenham), i. 59): see Joseph Spence, Observations, Anecdotes, and Characters of Books and Men, ed. James M. Osborn, 2 vols. (Oxford: Clarendon Press, 1966), no. 165, and appendix on ii. 625, for context.

${ }^{54}$ Johnson, Lives, iv. 82-3.

${ }^{55}$ Works of John Wilmot, Earl of Rochester, ed. Harold Love (Oxford: Oxford University Press, 1999), 72; its fame confirmed by Steele's quotation in no. 242 of The Tatler, iii. 242.

${ }^{56}$ Lonsdale (Johnson, Lives, iv. 352) points out that 'P's editors do not note the borrowing SJ has in mind', referring to Pope, TE, vi. 334-6. 
Dunciad' Pope rehearsed a commonplace argument about affectation and hypocrisy ('all vain pretenders') being the most proper subjects for satire. ${ }^{57}$ Johnson takes him absolutely at his word, implying that anyone who writes harsh satire when his nature is reticent is a sort of hypocrite, and that Pope is dishonest twice over to publish a paradox that is both morally frivolous and stolen. Paul Fussell has described the 'dualistic vision' that the earlier generation of Scriblerian satirists had of human nature, 'a surface of contempt, disparagement, and ridicule masking something quite different, namely, an implicit faith in man's capacity for redemption'. ${ }^{58}$ They were often contented, moreover, to let that doubleness cast a fog of irony over their own ethical positions: in his 'Epistle to Bolingbroke' Pope wrote of the 'Man divine whom Wisdom calls here own' as an immortal thing, half angelic, '- except (what's mighty odd) / A Fit of Vapours clouds this Demi-God'. Bolingbroke himself identified Swift as a 'hypocrite reversed', so determined to preserve his integrity that he dissembled his piety and virtue under a false display of irreverence. ${ }^{59}$ By 1755 Samuel Johnson seems to have felt that these ironic, doubled ethical positions were at best affectations, and at worst dishonest. In the Dictionary he leaves them to create their own impression of unsound sophistication, fundamentally at odds with the strenuous virtue to which Swift and Pope also laid claim.

Examples like these support the received idea that there was a shift in literary opinion around 1750 against satire, a shift that went hand in hand with a new 'Age of Sensibility', and with an emerging urban commercial class that was self-consciously

\footnotetext{
${ }^{57}$ Pope, Poems (Longman), iii. 132; see Elkin, Augustan Defense, 173, for the commonplace.

${ }^{58}$ Paul Fussell, The Rhetorical World of Augustan Humanism: Ethics and Imagery from Swift to Burke (Oxford: Oxford University Press, 1965), 112.

${ }^{59}$ Thomas Sheridan, The Life of the Rev. Dr. Jonathan Swift (1784), A2v .
} 
sentimental and polite. ${ }^{60}$ This vision of the British eighteenth century is settled, but historians have begun recently to revise and qualify it. Graphic satire and popular fiction provide the principal evidence that the British nation continued to wallow in cruelty, coarseness and hilarity, even while the philosophers and novelists insisted on its growing refinement. ${ }^{61}$

Looking at the more complex picture we now have of the mid century, one theme that emerges from contemporary commentary is the increasing dissatisfaction of writers with the instrumental emphasis of earlier accounts of satire - the abiding concern of the Scriblerian generation, that is, with satire's capacity (or failure) to instruct, to chastise, to vex or to forewarn. ${ }^{62}$ The enlightenment 'science of man' directed the attention of philosophers towards 'moral causes', as David Hume termed them, the full range of circumstances 'which are fitted to work on the mind as motives or reason, and which render a peculiar set of manners habitual to us'. ${ }^{63}$ But nonphilosophers also wanted more complete accounts of the dynamics of social exchange. In 1765 Lord Chesterfield wrote a letter to his son against satire, basing his case on some acute psychological observations:

Wit is so shining a quality, that everybody admires it, most people aim at it, all people fear it, and few love it unless in themselves. A

\footnotetext{
${ }^{60}$ See Festa.

${ }^{61}$ Vic Gatrell, City of Laughter: Sex and Satire in Eighteenth-Century London (London: Atlantic Books, 2006); Simon Dickie, Cruelty and Laughter: Forgotten Comic Literature and the Unsentimental Eighteenth Century (Chicago University Press, 2011); [Carolyn Lyell in this volume]

${ }^{62}$ See Marshall's chapter?

${ }^{63}$ David Hume, Essays Moral, Political and Literary, ed. Eugene F. Miller (Indianapolis: Liberty Fund, 1985), 198.
} 
man must have a good share of wit himself to endure a great share of it in another. When wit exerts itself in satire it is a most malignant distemper; wit it is true may be shown in satire, but satire does not constitute wit, as most fools imagine it does. A man of real wit will find a thousand better occasions of showing it. Abstain therefore most carefully from satire, which though it fall upon no particular person in company, and momentarily from the malignity of the human heart, pleases all; upon reflection, it frightens all too, they think it may be their turn next [...] Fear and hatred are next door neighbours. The more wit you have the more good nature and politeness you must show, to induce people to pardon your superiority, for that is no easy matter. ${ }^{64}$

The outlines of the old defence of satire are still visible here, particularly Dryden's design for the reception of 'fine raillery' - 'a witty man is tickled when he is hurt in this manner, and fool feels it not'. ${ }^{65}$ There are also shades of the highly qualified defence of satire that Addison made in The Freeholder no. 45: that while 'Detraction and Obloquy' always gets an eager response, the pleasure they give lasts only a moment, and the satirist 'must be a very ill Man, if by such a Proceeding he could please himself' ${ }^{66}$ The difference is that Chesterfield's thinking is focused not on the satirist but on the rest of the company, and beyond them on the full range of Humean moral causes in which acts of satire are set. For all his worldliness, Chesterfield shows both the moral acuity and, more unexpectedly, the suspicion of cynicism that

\footnotetext{
${ }^{64}$ Lord Chesterfield's Letters, ed. David Roberts (Oxford: Oxford University Press, 1992), 345.

${ }^{65}$ Dryden, 'Disourse', 423, echoing Persius 1.116-7, cited above.

${ }^{66}$ Joseph Addison, The Freeholder, ed. James Leheny (Oxford: Clarendon Press, 1979), 237.
} 
characterize contemporary Scottish philosophers. As David Hume asked in his second Enquiry (1751), 'why rake into those corners of nature which spread a nuisance all around? Why dig up the pestilence from the pit in which it is buried? The ingenuity of your researches may be admired; but your systems will be detested' ${ }^{67}$ Chesterfield understands the delicate adjustments people must make to their sentiments if they are to avoid jeopardizing the sympathy of others - Adam Smith, for example, made similar calculations in the Theory of Moral Sentiments (1759). ${ }^{68} \mathrm{He}$ understands, as Lord Kames put it in The Elements of Criticism (1762), that the 'irregular use made of a talent for wit or ridicule, cannot long impose on mankind. It cannot stand the test of correct or delicate taste'. ${ }^{69}$ Chesterfield's letter shows once again how hard it was by the mid eighteenth century to maintain the postures of satiric heroism that had served Pope and Swift so well only a few decades earlier.

The positions taken by Johnson and Chesterfield in these comments and quotations stand as examples of the moral pressure that was placed on satirists from midcentury. ${ }^{70}$ One way of easing this pressure was to take a step back from the ethical dilemmas, and to fictionalize both the individuals who face them and the people that they satirize. Chesterfield's comment about the momentary malignity of humanity assumes that everyone - author, victim, and audience - is implicated in the satirical

\footnotetext{
${ }^{67}$ David Hume, Enquiries Concerning Human Understand and the Principles of Morals, ed. P.H. Nidditch, $3^{\text {rd }}$ ed. (Oxford: Clarendon Press, 1975), 279.

${ }^{68}$ See Adam Smith, The Theory of Moral Sentiments, ed. D.D. Raphael and A.L. Macfie (Oxford: Clarendon Press, 1976), 43-50.

${ }^{69}$ Henry Home, Lord Kames, Elements of Criticism, ed. Peter Jones, 2 vols. (Indianapolis: Liberty Fund, 2005), i. 262-3.

${ }^{70}$ See Fowler, Rounce [Think of those who stil step up: Churchill, obviously]
} 
event. ${ }^{71}$ Isaac Barrow had come to the same conclusion in 1678: 'satyrical taunts do owe their seeming piquancy, not to the speaker, or his words, but to the subject, and the hearers; the matter conspiring with the bad nature, or the vanity of men' ${ }^{72}$ Fiction provides a frame in which implicated audience, victim and satirist can be individualized safely.

Accordingly, satirists became stock characters in eighteenth-century novels and plays: examples include Mr. Spatter in David Simple (1744), Roderick Random's (1748) Miss Snapper, or Mr. Tinsel in Lennox's Female Quixote (1752). But none creates more doubt and confusion among her fellow characters than Mrs. Selwyn in Frances Burney's novel Evelina (1778). Evelina's unwanted suitor Sir Clement Willoughby himself a wit and practical joker - is excited by Mrs. Selwyn's banter, but is no match for her aggressive energy: 'she keeps alive a perpetual expectation of satire,' he complains, 'that spreads a general uneasiness among all who are in her presence; and she talks so much, that even the best things she says weary the attention' ${ }^{73} \mathrm{Mr}$. Villars, Evelina's angelic but distant mentor, diagnoses gender trouble: 'for, in studying to acquire the knowledge of the other sex, she has lost all the softness of her own'. It is Evelina herself, however, who has the best understanding of how Mrs. Selwyn exemplifies the moral limitations of the satirist's role:

It is true, Mrs. Selwyn is very obliging, and, in every respect, treats me as an equal; but she is contented with behaving well herself, and does not, with a distinguishing politeness, raise and support me with others. Yet I mean not to blame her, for I know she is sincerely my

\footnotetext{
${ }^{71}$ See Curran

72 Barrow, Several Sermons, 74.

${ }^{73}$ Frances Burney, Evelina, ed. Edward A. Bloom (London: Oxford University Press, 1968), 343.
} 
friend; but the fact is, she is herself so much occupied in conversation, when in company, that she has neither leisure nor thought to attend to the silent. ${ }^{74}$

Evelina sees that Mrs. Selwyn's self-directed motives for ridicule correspond with her obsessive focus on the satirical object before her. Both are ungenerously narrow, and both mean that she cannot do her common duty within the larger social group. This narrowness is understood by Evelina as a failure to think and to distinguish, which rather compromises Mrs. Selwyn's claim to intellectual distinction. But it is significant that a more polite and rational manner is assumed to be within her power. Mrs. Selwyn is much more than a humour character, for all her narrowness. When Lady Mary Wortley Montagu had fought back against Pope's attacks on her, she represented her opponent as a sort of vicious animal, and his aggression as a bodily compulsion. Of course she did not neglect to mention his physical deformity in this context: it 'shows the Uniformity of Fate, / That one so odious should be born to hate' ${ }^{75}$ She told Joseph Spence that Addison had once advised her to 'leave him as soon as you can [...]; he has an appetite to satire'. ${ }^{76}$ With Burney's Mrs. Selwyn, one the other hand, we can see all the way around the satirist's psychological circumstances. We see her appetite for satire hardened by a will to dominate, yet subtilized by knowledge and observation (always of others, never of the self); we see

\footnotetext{
${ }^{74}$ Burney, Evelina, 294.

${ }^{75}$ Lady Mary Wortley Montagu, Essays and Poems and Simplicity, a Comedy, ed. Robert Halsband and Isobel Grundy (Oxford: Clarendon Press, 1977), 268; see Deutsch below

${ }^{76}$ Spence, Observations, no. 748; cf. Colley Cibber, Letter from Mr. Cibber to Mr. Pope (1742), 65: 'When you used to pass your Hours at Button's you were even there remarkable for your satirical Itch of Provocation'.
} 
it wielded to defend the unprotected, but we note its inflexibility, its useless when kindness and encouragement are required; and above all we see how it mortifies and discourages everyone it touches, both friend and foe. By the end of the eighteenth century satire has itself become an object for social description and moral anatomization. And this, as much as anything, marks the period of satire's ascendancy over eighteenth-century culture. 